\title{
1 \\ Building Passion and Potential for Creative Learning in Higher Education
}

\author{
Susan Keller-Mathers \\ Buffalo State College, Buffalo, NY
}

Building passion and potential for creative learning in higher education involves deliberately seeking to understand, appreciate, and teach for creativity. Recognizing the urgent need for creativity and problem solving skills, and understanding that instructors must embrace creative learning for themselves first, is central. Creativity cannot be left to chance. Developments in the field of creativity, both with regard to defining aspects of creativity and providing frameworks for integrating creative learning into higher education practices are discussed.

\section{Introduction}

E xperts in any field of study must keep pace with change. This requires the ability to scan large bodies of information, synthesize knowledge, continually acquire new skills, and capture the essence of what is most important. Leading a field requires expertise in combination with a strong sense of curiousity and original insights to generate new concepts, theories, skills, processes, and products. These thought leaders and creative problem solvers exemplify the creative learner. Mere mastery of a discipline does not satisfy their thirst for understanding. They continually question. They have a drive to uncover mysteries. They delve into areas of ambiguity, allow contradictory perspectives to emerge, and invite seemingly unsolvable problems to percolate. They are never satisfied with what is known. These individuals go beyond and display a passionate love of what they are doing, a rich future image, high energy, and a love of a challenge (Millar, 2010; Torrance, 1983).

The activities, skill, and knowledge development in higher education that mirror exceptional professional practices also engage students in creative learning. The accomplishment of the mastery of a body of knowledge, the wonder and excitement of discovery, and the satisfaction of the generation of new thought, reflect best practices in teaching and learning that demand learners be fully engaged, mindful, and creative.

The first step toward a more deliberate development of creative learning and teaching practices in higher education is to make explicit three aspects of creative growth. First, the recognition of 
the urgent need for creativity and problem solving is necessary. To grasp this fully, a basic understanding of the dimensions of creativity is essential. Second, the importance of creative learning for self first and then for nurturing others is important to recognize. To fully bring creative teaching and learning to the classroom, one must first value and model creative learning. Third, a basic understanding of the diverse ways to deliberately develop creativity in higher education is necessary. Each is discussed in this article.

\section{An Urgent Need for More Creativity and Problem Solving}

The desire to harness future possibilities creates an urgent need for creativity in the world. It has been said many times that change is inevitable and growth is optional. Leading change, through creative thought and action, rather than reacting to change, provides the means to shape a productive future. Placing a creativity lens over teaching and learning practices provides a way to step back from content, from disciplinary expertise and current perspectives on pedagogy and ask specifically "What is creativity?" so to better understand the dimensions that make it urgently needed.

Twenty-first century skill advocates such as the Partnership for $21^{\text {st }}$ Century Skills (2008) articulate skills necessary for the future as student outcome areas, including creativity and innovation skills, critical thinking and problem solving skills, communication and collaboration skills, life and career skills, and flexibility and adaptability skills. Revisions of Bloom's taxonomy articulated creativity as a central aspect of the taxonomy (Anderson \& Krathwolh, 2001). In the updated taxonomy, creating replaced synthesis and is defined as "Putting elements together to form a novel, coherent whole or make an original product" involving generating, planning, and producing (Krathwolh, 2002, p. 215). Embedding creativity into education requires knowing the scholarly work toward defining dimensions of creativity and research-based practices to embed $21^{\text {st }}$ century skills in educational practices. To that end, several key developments in defining aspects of creativity, both historically and currently, are discussed next. They are presented not as a comprehensive view but as a representative sample of the rich history and current theory in the field of creativity toward an understanding of the multifaceted nature of creativity.

J.P. Guilford's 1950 speech as President of the American Psychological Association is most often credited as the beginning of the modern study of creativity. He urged psychologists to study the neglected area of creativity. The developer of the Structure of Intellect Model, Guilford (1977) described a theory of intelligence that included up to 150 different aspects of intelligence, including creative abilities. At the same time, at the Institute of Personality Assessment and Research, researchers (MacKinnon, 1962, 1978) were studying highly creative individuals and E. Paul Torrance (1966, 1972) was developing classic creativity tests and examining children's creativity. Alex Osborn (1953) was utilizing his brainstorming technique, articulating a deliberate creative problem solving process and planting the seeds for university-level studies in creativity (Parnes \& Noller, 1972). Mel Rhodes (1961) described a productive framework for describing the dimensions of creativity as the "four P's" or person, process, product, and press. During the same time period, other researchers and practitioners were contributing to the foundation for the study and practice of creativity in education and business (i.e., Barron, 1969; de Bono, 1969; Gordon, 1961; Taylor, 1973).

Current work in the field builds directly from these foundations and includes expanding studies of creativity at the university level (Murdock \& KellerMathers, in press; Parnes, 1999). Simonton (1988, 2010) examined eminence, genius, and creativity and described eminence, genius, and a fifth "P" of creativity as "persuasion," while Csikszentmihalyi (1990, 2003) described the concept of flow and optimal experiences. Amabile (1998; Amabile \& Kramer, 2010) described an intrinsic motivation theory, aspects of the environment conducive to creativity, and the components leading to creative productivity including task motivation, domain relevant skills, and creativity relevant skills. Sternberg 
(1985) articulated the Triarchic Theory of Intelligence that expands intelligence to include analytical, creative, or synthetic and practical intelligence and re-conceptualized admissions to Tufts University to reflect wisdom and the expanded view of intelligence (Sternberg, Jarvin, \& Grigorenko, 2009).

\section{Creativity Starts With Self}

Fully nurturing the creative potential of others requires personally modeling the behaviours, attitudes, and actions consistent with a creative learner. Development of one's creative expression is therefore first. This can look very different in varied talent areas, cultures, and preferred ways of operating. Further, creative characteristics displayed as strengths by one person may be very different than that of another. Some classic characteristics of creativity articulated by early researchers such as Guilford and MacKinnon include fluency, flexibility, originality, elaboration, risk-taking, curiosity, complexity, imagination, independence, openness, tolerance of ambiguity, and capacity to make order from chaos. The excitable, original, outgoing way of someone who typically might be called an 'idea person' and another person's calm, thoughtful, deliberate persistence to craft an elegant solution may each represent aspects of creativity and the potential to contribute to unique, useful, and well-crafted outcomes and products. Illuminating the creative strengths and capitalizing on the talents of the individual is central to understanding one's creative self, realizing that "I am creative."

Many factors impact one's ability to develop creativity. Some constraints such as availability of resources and expertise can be outside of one's immediate influence. Others, such as attitude, are clearly within a healthy individual's control. Noller (Parnes, Noller, \& Biondi, 1977) articulated the central nature of attitude in her classic definition of creativity as $\mathrm{C}=\mathrm{fa}(\mathrm{K}, \mathrm{I}, \mathrm{E})$. She explains that creativity is focused on the use of knowledge, imagination, and evaluation with a subscript "a" for attitude. Murdock described three affective thinking skills that are central to the development of creative problem solving skills (Puccio, Murdock, \& Mance, 2007). These attitudes toward creativity included tolerance for ambiguity, tolerance for complexity, and openness to novelty. Without these skills, fully engaging in the messiness and multifaceted nature of newness where forward thinking flourishes is blocked by self-imposed constraints. Attitude counts when it comes to creativity.

\section{Don't Leave Creativity to Chance}

If we want to do a better job at teaching skills such as those suggested by the Partnership for $21^{\text {st }}$ Century Skills (2008), we must "engage in solving complex multidisciplinary open ended problems; developing creativity and entrepreneurial thinking, which is a skill set highly associated with job creation; and making innovative use of knowledge, information and opportunities to create new services processes and products" (p. 1). Educators must ask themselves, "To what degree do I deliberately promote creativity?"

Mel Rhodes' (1961) classic framework for creativity provides a productive view to examine the aspects of creativity for teaching and learning. Bringing these elements to a more conscious level and articulating their dimensions enables educators to be more deliberate. Both the physical and psychological conditions necessary for creative thought must be considered. The appreciation and understanding of the diverse characteristics and ways people engage creative processes, both naturally and deliberately, can be improved. The specific dimensions of products and outcomes that lead to more novel, useful, and well-crafted products can be articulated and described both generally and within specific professions.

Articulating a model for integrating creativity into content and recent work utilizing Torrance's (1979) framework provides one of the few deliberate creative teaching and learning models to incorporate creativity deliberately (Murdock \& Keller-Mathers, 2008). Structurally, the Torrance Incubation Model of Creative Teaching and Learning (TIM) contains a specific content and an aspect of creativity articulated through goals, and deliberately integrated at each stage of (1) Heightening Anticipation; (2) Deepening Expectations; and (3) Extending the Learning (Murdock \& Keller-Mathers, 2008). 
The engagement process begins with heightening anticipation before and/or at the beginning of a learning episode. Using incompleteness, arousal, and creative tension provides a means to 'warm up' to the learning. Strategies such as getting attention and creating desire to know assist the teacher in more explicitly engaging the learner fully before and at the beginning of a learning episode.

To deepen expectations, additional strategies, described as metaphors include for example "digging deeper" to go beyond the surface and see what is initially hidden or searching for unanswered questions by "getting into deep water" (Torrance $\&$ Safter, 1990, 1999). It involves considering what is done during a learning episode to deepen student expectations for learning regarding the main content of the lesson and the creativity component integrated into this stage.

In Extending the Learning, strategies in the form of metaphors also assist with using the model and include, for example, giving the information personal meaning by "singing in one's own key" and enlarge one's view of the future by "shaking hands with tomorrow." It involves deliberate consideration of what instructors do at the end and after the learning episode to extend the learning regarding the main content of the lesson and the creativity component integrated into this stage.

Implemented effectively, TIM provides the conditions for incubated thoughts beyond the timeframe of the learning episode. MacKinnon (1978) stated "The moment of insight and inspiration may be sudden and brief, but it comes usually only after prolonged searching" (p. 189). Deep thinking involves thinking well beyond when a concept is introduced, and occurs after one engages in some understanding of a concept that has complexities, involves ambiguity and novelty, and has unanswered questions that intrigue and perplex the learner. TIM is designed to provide the conditions for incubation to occur at the back end of the model.

When examining what aspect of creativity should be incorporated, it is important to deliberately select key aspects of creativity while continuing to keep the framework of the four P's in mind. A productive framework from which to select skills includes, for example, the research-based creativity skills described by Torrance for use with the incubation model (Torrance \& Safter, 1999). Those skills include: The Problem, Produce \& Consider Many Alternatives, Be Flexible, Be Original, Highlight the Essence, Elaborate But Not Excessively, Keep Open, Be Aware of Emotion, Put Your Ideas Into Context, Combine \& Synthesize, Visualize It Rich \& Colourfully, Enjoy \& Use Fantasy, Make It Swing Make It Ring, Look At It Another Way, Visualize the Inside, Breakthrough Extend the Boundaries, Let Humour Flow \& Use It, and Get Glimpses of the Future.

Alternatively, to target thinking skills that are specifically aligned with a creative problem solving process, a set of cognitive and affective skills can be used to select skills essential to creative problem solving to integrate into a learning episode. Described as part of the Thinking Skills Model of Creative Problem Solving (Puccio et al., 2007; Puccio, Mance, \& Murdock, 2011) and built from the seminal work of Osborn (1953) and Parnes (1966), the skills align with seven steps of the process. The steps (as well as the cognitive and affective skills for each) include: Assessing the Situation (Diagnostic Thinking \& Mindfulness), Exploring the Vision (Visionary Thinking \& Dreaming), Formulating Challenges (Strategic Thinking \& Sensing Gaps), Exploring Ideas (Ideational Thinking \& Playfulness), Formulating Solutions (Evaluative Thinking \& Avoiding Premature Closure), Exploring Acceptance (Contextual Thinking \& Sensitivity to Environment), and Formulating a Plan (Tactical Thinking \& Tolerance for Risk). Further three affective skills that are described as essential in all steps of the process include: Openness to Novelty, Tolerance for Ambiguity, and Tolerance for Complexity.

These two research-based skills sets (or any other sound theoretical framework for creativity skills or concepts) can form the basis of strategically selected skills related to creativity to integrate as part of TIM.

\section{Conclusion}

Building passion and potential for creative teaching and learning involves an awareness and understanding 
of the urgent need for creativity. It also involves one's own creative growth first, as well as an eye toward improving practice to more deliberately nurture creative learning in others. One must be a creative teacher and a creative learner while understanding that teaching for creativity involves more than a new twist on an old way of presenting material (KellerMathers, 2009). To engage in creative teaching and learning, creativity is named, developed, supported, validated, and celebrated.

\section{References}

Amabile, T.M. (1998). How to kill creativity. Harvard Business Review, 76(5), 76-87.

Amabile, T.M., \& Kramer, S.J. (2010). What really motivates workers. Harvard Business Review, $88(1), 44-45$.

Anderson, L. \& Krathwolh, D. (2001). A taxonomy for learning, teaching and assessing: A revision of the Bloom's taxonomy of educational objectives. New York, NY: Longman.

Barron, F.X. (1969). Creative person and creative process. New York, NY: Holt, Rinehart \& Winston.

Csikszentmihalyi, M. (1990). Flow: The psychology of optimal experience. New York, NY: Harper and Row.

Csikszentmihalyi, M. (2003). Good business: Leadership, flow, and the making of meaning. New York, NY: Penguin Books.

de Bono, E. (1969). The mechanism of the mind. New York, NY: Simon and Schuster.

Gordon, W.J.J. (1961). Synectics: The development of creative capacity. New York, NY: Harper \& Row.

Guilford, J.P. (1950). The 1950 presidential address to the American Psychological Association.
American Psychologist, 5, 444-454.

Guilford, J.P. (1977). Way beyond the IQ. Buffalo, NY: Bearly Limited.

Keller-Mathers, S. (2009). Creative teaching. In B. Kerr (Ed.), Encyclopaedia of giftedness, creativity, and talent (pp. 197-200). Thousand Oaks, CA: Sage.

Krathwolh, D.R. (2002). A revision of Bloom's taxonomy: An overview. Theory Into Practice, 41(4), 212-218.

MacKinnon, D. (1962). The nature and nurture of creative talent. American Psychologist, 17, 484-495.

MacKinnon, D. (1978). In search of human effectiveness: Identifying and developing creativity. Buffalo, NY: Bearly Limited.

Millar, G. (2010). The power of creativity: Results of the 50-year follow up to the Torrance Longitudinal Study of Creative Behavior. Bensenville, IL: Scholastic Testing.

Murdock, M. \& Keller-Mathers, S. (2008). Teaching and learning creatively with the Torrance Incubation Model: A research and practice update. International Journal of Creativity and Problem Solving, 18(2), 11-33.

Murdock, M. \& Keller-Mathers, S. (in press). Programs and courses in creativity. In M. Runco \& S. Pritzker (Eds.), Encyclopedia of creativity (2nd ed.). Thousand Oaks, CA: Academic Press.

Osborn, A. (1953). Applied imagination. New York, NY: Charles Scribner's Sons.

Parnes, S.J. (1966). Programming creative behavior. Buffalo, NY: State University of New York.

Parnes, S.J. (1999). Programs and courses in 
creativity. In M. Runco \& S. Pritzker (Eds.), Encyclopedia of creativity (pp. 465-478). Thousand Oaks, CA: Academic Press.

Parnes, S. \& Noller, R. (1972). Applied creativity: The creative studies project. Journal of Creative Behavior, 6(1), 11-22.

Parnes, S., Noller, R., \& Biondi, A. (1997). Guide to creative action. New York, NY: Scribners.

Partnership for $21^{\text {st }}$ Century Skills. (2008). 21 $1^{\text {st }}$ century skills, education and competitiveness: $A$ resource and policy guide. Tuscon, AR: Author.

Puccio, G., Murdock, M., \& Mance, M. (2007). Creative leadership: Skills that drive change. Thousand Oaks, CA: Sage.

Puccio, G., Mance, M., \& Murdock, M. (2011). Creative leadership: Skills that drive change. $\left(2^{\text {nd }} E d.\right)$.Thousand Oaks, CA: Sage.

Rhodes, M. (1961). An analysis of creativity. Phi Delta Kappan, 24(7), 305-310.

Simonton, D.K. (1988). Creativity, leadership, and chance. In R.J. Sternberg (Ed.), The nature of creativity (pp. 386-426). New York, NY: Cambridge University Press.

Simonton, D.K. (2010). Creativity in highly eminent individuals. In J.C. Kaufman \& R.J. Sternberg (Eds.), The Cambridge handbook of creativity (pp.174-188). New York, NY: Cambridge University Press.

Sternberg, R.J. (1985). Beyond IQ: A triarchic theory of human intelligence. New York, NY: Cambridge University Press.

Sternberg, R.J., Jarvin, L., \& Grigorenko, E.L. (2009). Teaching for wisdom, intelligence, creativity, and success. Thousand Oaks, CA: Corwin.
Taylor, C.W. (1973). Developing effectively functioning people, the accountable goal of multiple talent teaching. Education, 94(2), 99-110.

Torrance, E.P. (1966). Torrance tests of creative thinking. Princeton, NJ: Personnel Press.

Torrance, E.P. (1972). Can you teach for creativity? Journal of Creative Behaviour, 6, 236-262.

Torrance, E.P. (1979). An instructional model for enhancing incubation. Journal of Creative Behavior, 13(1), 23-35.

Torrance, E.P. (1983). The beyonders in a thirty year longitudinal study. Roeper Review, 15(3), 131-151.

Torrance, E.P. \& Safter, H.T. (1990). The incubation model of learning and teaching: Getting beyond the aha. Buffalo, NY: Bearly Limited.

Torrance, E.P. \& Safter, H.T. (1999). Making the creative leap beyond. Buffalo, NY: Creative Education Foundation.

\section{Biography}

Susan Keller-Mathers (Ph.D.) is an Associate Professor of Creative Studies at the International Center for Studies in Creativity at Buffalo State. She chairs the School of Profession's Curriculum Committee and focuses on the scholarship of creative teaching and learning in the schools, in higher education, and in training applications. 